\title{
Description of plant communities on Half Moon Island, Antarctica
}

\author{
Daniela Schmitz $\mathbb{1}^{\mathrm{a}}$, Jair Putzke ${ }^{\mathrm{b}}$, Margéli Pereira de Albuquerque $\mathbb{1}^{\mathrm{b}}$, Adriano Luis Schünemann $\mathbb{( \mathbb { O }}^{\mathrm{b}}$, \\ Frederico Costa Beber Vieira ${ }^{b}$, Filipe de Carvalho Victoria $\mathbb{0}^{\mathrm{b}}$ \& Antônio Batista Pereira $\mathbb{0}^{\mathrm{b}}$
}

aDepartamento de Biologia Vegetal, Laboratório de Ecologia Evolutiva de Plantas, Universidade Federal de Viçosa, Viçosa, Brazil;

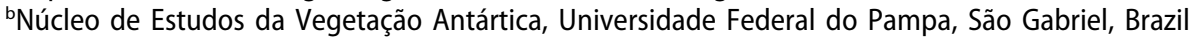

\begin{abstract}
During February-March of the austral summers of 2013/14 and 2014/2015, fieldwork was performed on Half Moon Island, South Shetland Archipelago, Antarctica, to evaluate the distribution and abundance of mosses and lichens, as well as to describe and map the plant communities there. The quadrat $(20 \times 20 \mathrm{~cm})$ sampling method was employed in a phytosociological study that aimed to describe these communities. The area was mapped using an Astech Promark $\|^{\oplus}$ DGPS, yielding sub-metric precision after post-processing with software. The number of species totalled 38 bryophytes, 59 lichens, only one flowering plant (Deschampsia antarctica Desv.), and two macroscopic terrestrial algae. Five types of plant communities were identified on the island, as follows: (1) fruticose lichen and moss cushion, (2) moss carpet, (3) muscicolous lichen, (4) crustose lichen and (5) moss turf.
\end{abstract}

\section{KEYWORDS}

Phytosociology; Antarctic plant distribution; bryophytes; lichens; plant community mapping

\section{ABBREVIATION}

IES: index of ecological significance

\section{Introduction}

Half Moon Island $\left(62^{\circ} 35^{\prime} \mathrm{S}\right.$ and $\left.59^{\circ} 55^{\prime} \mathrm{W}\right)$ is one of the smallest islands in the South Shetland Archipelago, Antarctica. This island is visited daily by tourists, who are mainly attracted by its penguin colonies and by the fact that, apart from the giant petrel, all birds that reproduce in the Antarctic can be found on this island (Olrog 1958; Favero \& Silva 1991; Esponda et al. 2000). Teniente Camara Base (Argentina) is located on this island.

The Antarctic flora is composed mainly of bryophyte and lichen species adapted to harsh conditions and low temperatures, with 111 moss species described and 360 lichen species accepted by taxonomists occurring in the region, although recent studies indicate that the number of lichen species could actually be as high as 500 species. Regarding angiosperms, only two species of native flowering plants have been described from Antarctica, which are Deschampsia antarctica (Desv.) and Colobanthus quitensis (Kunth) Bartl. (Pereira \& Putzke 1994; Øvstedal \& Lewis-Smith 2001, 2004; Putzke \& Pereira 2001; Chwedorzewska et al. 2008; Ochyra et al. 2008; Øvstedal \& Schaefer 2013).

The vegetation of Half Moon Island was first reported by Lindsay (1971) after a short-term excursion $(6 \mathrm{~h})$ in the area, but no reference has been made to any specific species. There are colonies of almost all representative Antarctic birds breeding on the island, in addition to colonies of seals resting in the area, which could suggest an association between the presence of these animals with the occurrence of plants there. Birds were counted on this island in some previous studies (Olrog 1958; Favero \& Silva 1991; Esponda et al. 2000). According to Esponda et al. (2000), there were 10 breeding species on this island in the Antarctic summer of 1995/96: chinstrap penguins (Pygoscelis antarctica; 3342 pairs), Cape petrels (Daption capense; eight), Wilson's storm petrels (Oceanites oceanicus; 377), black-bellied storm petrels (Fregetta tropica; seven), Antarctic cormorants (Phalacrocorax atriceps bransfieldensis; 29), Subantarctic skuas (Catharacta antarctica; three), South Polar skuas (C. maccormicki; 103), kelp gulls (Larus dominicanus; 39), Antarctic terns (Sterna vittata; 125) and greater sheathbills (Chionis alba; 11).

Tourism is on the rise in Antarctica, and Half Moon Island is one of the areas most visited by tourists. According to the Association of Antarctic Tourism Operators, tourism on this island has increased nearly eightfold from 1999 to 2014 (Bender et al. 2016). This has likely had an impact on the vegetation, which is a drawback for a plant community study. However, it also provides an opportunity to monitor environmental impacts and diminish future damage from anthropic activities (Esponda et al. 2000).

This study aimed to describe and map the distribution of plant communities on Half Moon Island in order to contribute to efforts to monitor the impact on plant communities of touristic activities there in the future.

CONTACT Frederico Costa Beber Vieira filipevictoria@unipampa.edu.br @ Núcleo de Estudos da Vegetação Antártica, Universidade Federal do Pampa, Avenida Antônio Trilha, 1847, São Gabriel, RS 97300-000, Brazil

(4) Supplementary data for this article can be accessed here 


\section{Materials and methods}

Half Moon Island is located in the South Shetland Archipelago, on the west side of the Antarctic Peninsula. It was visited during the 32nd Brazilian Antarctic Operation, carried out in two fieldwork seasons, both in February-March of the austral summers of 2013/14 and 2014/15. The Operation used the facilities of Argentina's Camara Base, which was established in 1952/53, and laboratories and equipment were installed in the proximity of La Morenita Hill. Shaped like a crescent moon, the island is located between latitudes of $62^{\circ} 34^{\prime} 50.57^{\prime \prime} \mathrm{S}$ and $62^{\circ} 35^{\prime} 54.04^{\prime \prime} \mathrm{S}$ and longitudes of $59^{\circ} 53^{\prime} 24.44^{\prime \prime} \mathrm{W}$ and $59^{\circ} 56^{\prime} 04.16^{\prime \prime} \mathrm{W}$. Its eastwest and north-south dimensions are both approximately $2 \mathrm{~km}$. With a total area of $152 \mathrm{ha}$, it is one of the smallest islands of the archipelago.

There are three main hills on the island, among which Gabriel Hill is the highest point on the island, reaching $101 \mathrm{~m}$ a.s.l. Penguin rockeries are concentrated on Baliza Point and are frequently visited by tourists during the summer.

The study of vegetal communities on the island started with a survey to locate the vegetated areas, and the collection and identification of the plant species occurring in the area. Species not identified in the field were sampled and identified later in the laboratory at Camara Base. Species identification was performed according to guides by Ochyra (1998), Ochyra et al. (2008) and Putzke \& Pereira (2001) for mosses, Ochyra et al. (2008) for liverworts, and Redon (1985), Øvstedal \& Lewis-Smith (2001) and Olech (2004) for lichens, using the usual procedures for each group.

A phytosociological survey was carried out using the methods of Braun-Blanquet (1964), adapted to the Antarctic situation (Victoria \& Pereira 2007). Southnorth lines were placed over each plant community formation, $5 \mathrm{~m}$ apart, with the total number of lines placed depending on the size of the vegetation formation, and sampling was maintained until no new species was found in five consecutive samples. Along each line, within each $5 \times 5 \mathrm{~m}$ plot, the abundance and coverage of each plant species was counted by using a $20 \times 20 \mathrm{~cm}$ quadrat subdivided with a grid into 100 sub-quadrats $2 \mathrm{~cm}^{2}$ in size. A total of 358 quadrats were sampled across the island, including all the observed patches of vegetation. Samples of vegetation were taken for subsequent identification if needed. The phytosociological data obtained were then used in the calculation of the IES. The IES combines the parameters of abundance (coverage and frequency, represented as $\mathrm{C}$ and $\mathrm{F}$, respectively), as follow: IES = F $(1+C)$ (Lara \& Mazimpaka 1998; Marques et al. 2005; Victoria \& Pereira 2007). The ShannonWiener's diversity index (Pitkanen 1998), Pielou's evenness index (Peet 1974) were used in order to describe the plant species diversity in each community formation (Ludwig \& Reynolds 1988).
The vegetal communities were mapped using an Ashtech Promark II ${ }^{\circledast}$ DGPS (Ashtech OEM), with data processed with the Astech Solutions ${ }^{\circledast}$ software. Vegetation spots on the maps produced were then circled and subsequently classified according to the IES.

The samples were dried at $40^{\circ} \mathrm{C}\left( \pm 5^{\circ} \mathrm{C}\right)$ in a kiln in the field, and deposited at the Bruno Edgar Irgang Herbarium in the Universidade Federal do Pampa in southern Brazil.

\section{Results}

The phytosociological analysis used data from 358 $20 \times 20 \mathrm{~cm}$ quadrats sampled in the field. The plants found included 37 bryophyte species (35 mosses and two liverworts), representing $33 \%$ of the bryophyte species described for Antarctica, and 59 lichen species that comprise $15 \%$ of those described for the Antarctic (Supplementary Table S1). Only one flowering plant (Deschampsia antarctica) and the macroscopic terrestrial algae Prasiola crispa (Lightfoot) Kützing and Prasiola calophylla (Carmichael ex Greville) Kützing were found on the island. The most species-rich family of mosses on the island was Bryaceae, followed by Pottiaceae, while the most speciose lichen families were Physciaceae and Teloschistaceae. These results demonstrate that, in spite of its small size, Half Moon Island has a great diversity of plant species compared to the amount of species existing around the Antarctic continent (Pereira \& Putzke 1994; Victoria et al. 2009; Victoria et al. 2013).

From the data obtained by phytosociological sampling of all the vegetation on Half Moon Island, the mosses Sanionia uncinata (Hedw.) Loeske and Sanionia georgico-uncinata (Müll. Hal.) Ochyra \& Hedenäs, combined herein as Sanionia spp., were the most frequently found species, followed by the lichen Usnea aurantiaco-atra (Jacq.) Bory (Table 1).

According to this phytosociological study on the vegetation of Half Moon Island, five types of plant communities were identified (Table 2, Fig. 1) covering approximately 19.17 ha of the island's surface, which represents $12.5 \%$ of the total island area. These communities were mapped (Fig. 2) and were characterized according to Lindsay (1971), as presented in Table 2.

\section{Fruticose lichen community}

This community was found to consist mainly of fruticose lichens, such as Usnea aurantiaco-atra and Sphaerophorus globosus (Huds.) Vain., on slopes facing the north side of the island, as well as mosses like Sanionia uncinata and Polytrichastrum alpinum (Hedw.) G.L. Smith on the most stable surfaces of these slopes. This is the second largest community on the island. However, the difficulties in reaching its locations 
Table 1. List of the most frequently sampled representative species found in the phytosociological survey on Half Moon Island, Antarctica.

\begin{tabular}{|c|c|c|c|c|}
\hline Species & Group & $\begin{array}{l}\text { Number of } \\
\text { quadrats }^{\mathrm{a}}\end{array}$ & $\begin{array}{l}\mathrm{F}^{\mathrm{b}} \\
(\%)\end{array}$ & $\mathrm{IES}^{\mathrm{c}}$ \\
\hline Sanionia spp. & Moss & 257 & 71.78 & 234.81 \\
\hline $\begin{array}{l}\text { Usnea aurantiaco-atra (Jacq.) } \\
\text { Bory }\end{array}$ & Lichen & 124 & 34.63 & 63.17 \\
\hline $\begin{array}{l}\text { Polytrichastrum alpinum } \\
\text { (Hedw) G.L. Smith }\end{array}$ & Moss & 114 & 31.84 & 49.63 \\
\hline $\begin{array}{l}\text { Ochrolechia frigida (Sw.) } \\
\text { Lynge }\end{array}$ & Lichen & 110 & 30.62 & 40.85 \\
\hline Verrucaria sp. & Lichen & 83 & 23.18 & 29.27 \\
\hline Lecidea sciatrapha Hue & Lichen & 79 & 22.06 & 27.86 \\
\hline $\begin{array}{l}\text { Sphaerophorus globosus } \\
\text { (Huds.) Vain. }\end{array}$ & Lichen & 70 & 19.55 & 25.67 \\
\hline
\end{tabular}

${ }^{\mathrm{a}}$ Number of quadrats in which the species was recorded. ${ }^{\mathrm{b}}$ Species frequency in 358 quadrats. IES of specie considering all samples.

Table 2. Diversity analyses of the plant communities found on Half Moon Island, Antarctica. The number of species (S), specific diversity observed $\left(\mathrm{H}^{\prime}\right)$, expected species diversity $\left(H_{\text {max }}\right)$, and Pielou evenness $(J)$ are presented.

\begin{tabular}{lccccc}
\hline Community & $\mathrm{S}$ & $\mathrm{H}^{\prime}$ & $\mathrm{H}_{\max }$ & $\mathrm{J}$ & Area (ha) \\
\hline Fruticulose lichen & 37 & 1.3817 & 1.5682 & 0.8811 & 5.08 \\
Moss carpet & 51 & 1.3640 & 1.7075 & 0.7988 & 4.30 \\
Muscicolous lichen & 35 & 1.3327 & 1.5440 & 0.8631 & 0.64 \\
Crustose lichen & 39 & 1.4700 & 1.5910 & 0.9239 & 8.46 \\
Moss turf & 30 & 1.3330 & 1.4771 & 0.9024 & 0.70 \\
\hline
\end{tabular}

on slopes limited the number of phytosociological quadrat samples that could be taken to 36 , at which point new species stopped appearing in the samples. Thirty-seven plant species were identified $\left(\mathrm{E}=0.8811, \mathrm{H}^{\prime}=1.3817\right)$ comprising mosses, lichens and the grass Deschampsia antarctica (Table 3) that appears sparsely in both of the hillsides of La Morenita and Xenia hills.

Some areas are transitional between the moss Andreaea spp. and true fruticose lichen associations, and these are dominated by Usnea aurantiaco-atra among the saxicolous species and Sphaerophorus globosus, Cladonia borealis S. Stenroos, C. rangiferina (L.) Weber ex F.H.Wigg. and Stereocaulon glabrum (Müll. Arg.) Vain. among the muscicolous species. The confluence of these communities generates a well-defined complex, aggregating characteristic species of these communities and other important ones, which are mostly muscicolous lichens growing on Andreaea spp., such as Psoroma hypnorum (Vahl) Gray, P. cinammomeum Malme, Parmelia saxatilis (L.) Ach. and, most commonly, Ochrolechia frigida (Sw.) Lynge.

One formation almost exclusively inhabited by fruticose lichens (saxicolous Usnea aurantiaco-atra) is that found on a slope of high declivity that starts near the access to the beach north of Xenia Hill and then rises up to approximately $250 \mathrm{~m}$ a.s.l. from east to west. The small rock fragments in this formation are almost entirely covered by Usnea aurantiaco-atra, giving it a very high IES (reaching 425.00) here, followed by crustose saxicolous lichens, which together reached an IES of 266.43. Among the moss carpet species, only Sanionia spp. were registered here (IES $=115.43)$, covering areas where a small amount of fine soil particles was found. Among the cushion-forming mosses, Andreaea gainii Card., A. depressinervis Card. and Himantormia lugubris (Hue) I.M. Lamb were found sparsely, usually associated with other communities.

\section{Moss carpet community}

Moss carpet communities are mostly composed of the species Sanionia spp. (Table 4), which has the highest index of biomass in the Antarctic islands (Putzke \& Pereira 2001). This community is usually found on soft slopes or on slopes near drainage lines, forming
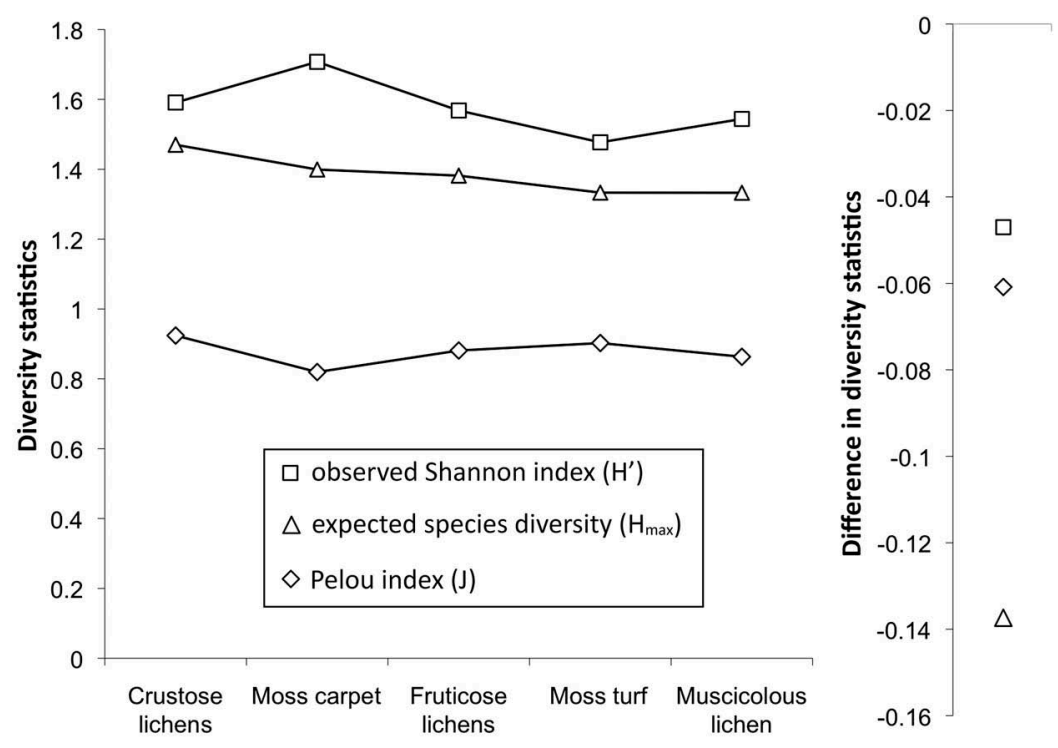

Figure 1. Diversity statistics of plant communities found in each community formation observed on Half Moon Island, maritime Antarctica. The differences in measurements means the significance of each index at the number of samples in each community formation. 


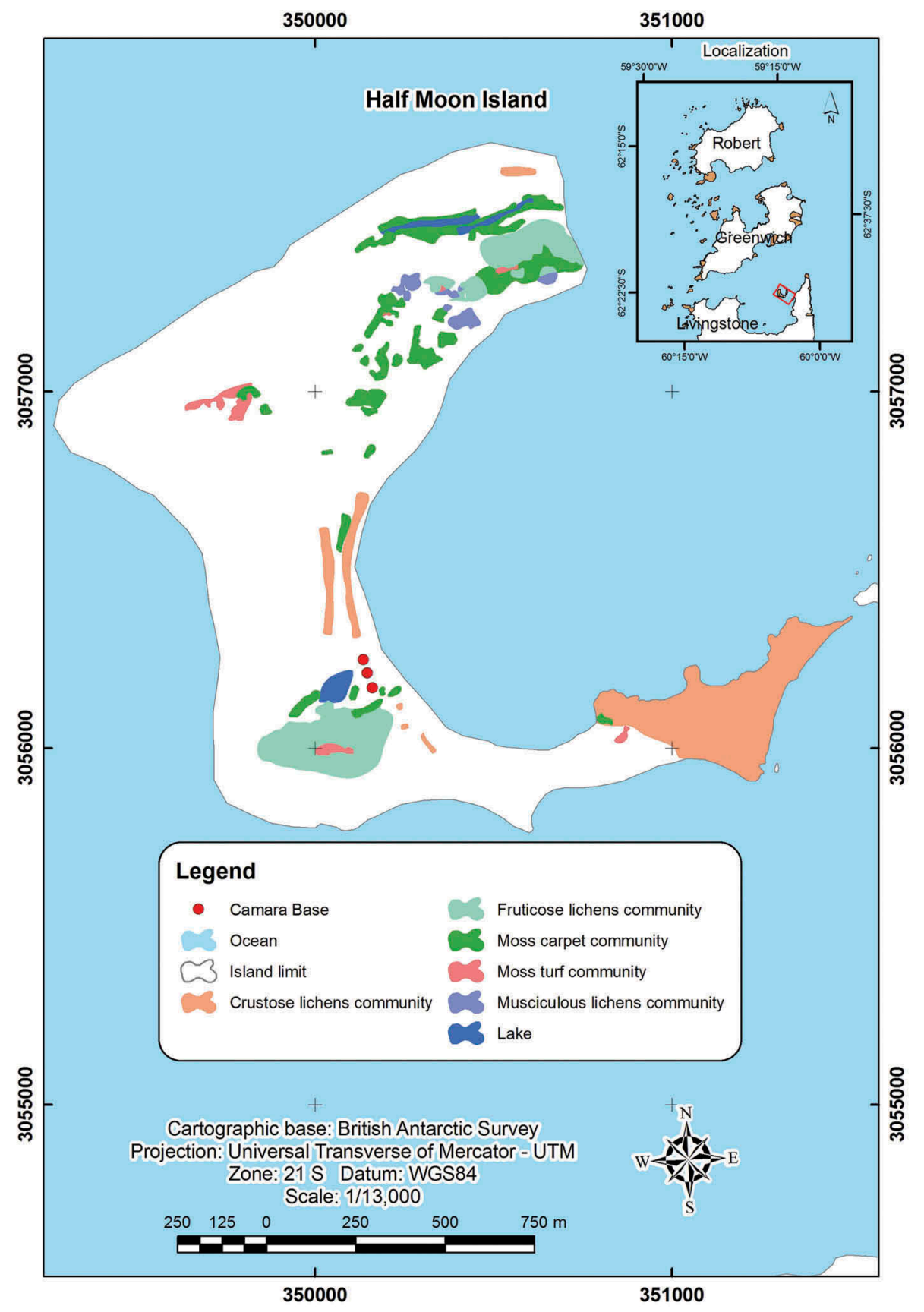

Figure 2. Distribution map of the plant communities on Half Moon Island, Antarctica.

extensive carpets both on the tops of hills and on areas adjacent to the beach level. Its occurrence is restricted to areas with a stable substrate. In this study, 51 species were identified from 191 quadrat samples of this community $\left(\mathrm{E}=0.7988 ; \mathrm{H}^{\prime}=1.3640\right)$, making it the most species-rich community at the study site.

The most extensive carpets are found along the northern beaches, at almost the level of the seashore, and also sparsely on the top of Xenia Hill, at the northern site of La Morenita Hill, and in the elevated areas between them. The carpets are formed mostly by Sanionia uncinata, along with some tufts of Brachythecium austrosalebrosum (Müll. Hal.) Kindb. at least $1 \mathrm{~m}$ in size, and sparsely some Warnstorfia fontinaliopsis (Müll. Hal.) Ochyra. There is still competition, especially with Bryum argenteum Hedw., B. cf nivale Müll. Hal. and B. pseudotriquetrum (Hedw.) Schwaegr., which are found together with the carpets of Sanionia uncinata or as completely isolated cushions. There are a few muscicolous lichens, but ring fungi are more frequent. In areas with small guano deposits, such as La Morenita in the south and Xenia and Gabriel hills in the north, the carpets are small and also furrowing among small rocks. Sometimes the carpets form large groups, which are frequently colonized by muscicolous lichens such as Ochrolechia frigida, Psoroma spp., Cladonia spp., Sphaerophorus globosus and Stereocaulon glabrum.

It is interesting to note that three different carpets are found in the northern portion of the island, almost at 
Table 3. Phytosociological data for the fruticose lichen communities on Half Moon Island, including the frequency (F), coverage (C) and IES for each species.

\begin{tabular}{|c|c|c|c|c|}
\hline Species & Group & $\mathrm{F}$ & C & IES \\
\hline Usnea aurantiaco-atra (Jacq.) Bory & Lichen & 100 & 3.25 & 425.00 \\
\hline Sanionia spp. & Moss & 61.11 & 0.888 & 115.43 \\
\hline Sphaerophorus globosus (Huds.) Vain. & Lichen & 47.22 & 0.666 & 78.70 \\
\hline Ochrolechia frigida (Sw.) Lynge & Lichen & 44.44 & 0.444 & 64.19 \\
\hline Lecidea sciatrapha Hue & Lichen & 38.88 & 0.444 & 56.17 \\
\hline Polytrichastrum alpinum (Hedw.) G.L. Smith & Moss & 36.11 & 0.5 & 54.16 \\
\hline Verrucaria sp. & Lichen & 33.33 & 0.388 & 46.29 \\
\hline Cladonia metacorallifera Asahina & Lichen & 33.33 & 0.361 & 45.37 \\
\hline Lecidea sp. & Lichen & 30.55 & 0.416 & 43.28 \\
\hline Andreaea depressinervis Card. & Moss & 27.77 & 0.527 & 42.43 \\
\hline Stereocaulon glabrum (Müll. Arg.) Vain. & Lichen & 22.22 & 0.472 & 32.71 \\
\hline Rhizoplaca aspidophora (Vain.) Redón & Lichen & 25 & 0.25 & 31.25 \\
\hline Andreaea gainii Card. & Moss & 19.44 & 0.222 & 23.76 \\
\hline Andreaea regularis Muell. & Moss & 16.66 & 0.222 & 20.37 \\
\hline Schistidium steerii Ochyra & Moss & 13.88 & 0.166 & 16.20 \\
\hline Dicranoweisia grimmiaceae (Müll. Hal.) Broth. & Moss & 13.88 & 0.138 & 15.81 \\
\hline Microglaena antarctica I.M. Lamb & Lichen & 13.88 & 0.138 & 15.81 \\
\hline Rhizocarpon polycarpum (Hepp) Th. Fr. & Lichen & 13.88 & 0.138 & 15.81 \\
\hline Psoroma cinammomeum Malme & Lichen & 11.11 & 0.166 & 12.96 \\
\hline Cladonia rangiferina (L.) Weber ex F.H. Wigg. & Lichen & 11.11 & 0.138 & 12.65 \\
\hline Buellia latemarginata Darb. & Lichen & 11.11 & 0.111 & 12.34 \\
\hline Ceratodon purpureus (Hedw.) Brid. & Moss & 11.11 & 0.111 & 12.34 \\
\hline Rhizocarpon geographicum (L.) DC. & Lichen & 11.11 & 0.111 & 12.34 \\
\hline Cystocoleus niger (Huds.) Har. & Lichen & 8.33 & 0.111 & 9.25 \\
\hline Polytrichum piliferum Hedw. & Moss & 8.33 & 0.083 & 9.02 \\
\hline Caloplaca athallina Darb. & Lichen & 5.55 & 0.055 & 5.86 \\
\hline Cladonia furcata (Huds.) Schrad. & Lichen & 5.55 & 0.055 & 5.86 \\
\hline Ochrolechia parella (L.) A. Massal. & Lichen & 5.55 & 0.055 & 5.86 \\
\hline Parmelia saxatilis (L.) Ach. & Lichen & 5.55 & 0.055 & 5.86 \\
\hline Bartramia patens Brid. & Moss & 2.77 & 0.027 & 2.85 \\
\hline Buellia russa (Hue) Darb. & Lichen & 2.77 & 0.027 & 2.85 \\
\hline Caloplaca cinericola (Hue) Darb. & Lichen & 2.77 & 0.027 & 2.85 \\
\hline Deschampsia antarctica Desv. & Grass & 2.77 & 0.027 & 2.85 \\
\hline Cephallozia sp. & Liverworth & 2.77 & 0.027 & 2.85 \\
\hline Leptogium puberulum Hue & Lichen & 2.77 & 0.027 & 2.85 \\
\hline Psoroma hypnorum (Vahl) Gray & Lichen & 2.77 & 0.027 & 2.85 \\
\hline Schistidium urnulaceum (Müll. Hal.) B.G. Sino & Moss & 2.77 & 0.027 & 2.85 \\
\hline
\end{tabular}

sea level, forming a 500-m long group, alongside two linear shallow lakes. The northernmost one contains only Sanionia uncinata, the middle one has S. uncinata together with some cushions of Bryum cf nivale, and the southernmost one has $S$. uncinata colonized by Cystocoleus niger (Huds.) Har. and Psoroma hypnorum with some small tufts of Polytrichastrum alpinum.

At the top of Xenia Hill, there is a carpet formed by Sanionia uncinata (exclusively associated with Bryum argenteum), and a small amount of muscicolous lichens associated with a water pond. No other place has this association on the island.

On the southern face of Xenia Hill, near its top, another carpet can be found, which is composed of $S$. uncinata partially covered by muscicolous lichens, such as Stereocaulon glabrum, Sphaerophorus globosus and Psoroma hypnorum, as well as Ochrolechia frigida and Cladonia spp. Some of these muscicolous lichens are associated with Andreaea, which is scarce in this association. This formation indicates that a muscicolous community probably occupies the area, and could replace the moss carpet formation in the future; however, further evaluations will be necessary to appraise this succession hypothesis.

On the flat area of Xenia Hill there are two other types of carpets, one of which is S. uncinata that is slightly colonized, but not enough to justify its characterization as muscicolous.

Another carpet is found high at the top of Gabriel Hill, formed by S. uncinata with patches of Andreaea spp. covering the rocks. This association is noteworthy because it is difficult to identify to which assemblage type it exactly belongs, but in fact there are two carpets here isolated by an Andreaea association.

A carpet was found ca. $20 \mathrm{~m}$ south of Camara Base, of which S. uncinata is the main component. In this area, the Sanionia coverage and frequency becomes larger towards the west. There are other components here, such as Andreaea spp. and Polytrichastrum alpinum among the mosses, but they are less representative towards the west, and the same trend occurs with saxicolous and muscicolous lichens here.

\section{Muscicolous lichen community}

This community represents the vast majority of the moss formations on the island. Thirty-five species were identified in this formation (Table 5), of which a total of 46 quadrats were evaluated $\left(\mathrm{E}=0.8631, \mathrm{H}^{\prime}=1.3327\right)$. There is a mix of many moss species, among which S. uncinata is the most abundant. The mosses are colonized by 
Table 4. Phytosociological data for the moss carpet communities on Half Moon Island, including the frequency (F), coverage (C) and IES for each species.

\begin{tabular}{|c|c|c|c|c|}
\hline Species & Group & $\mathrm{F}$ & C & IES \\
\hline Sanionia uncinata (Hedw.) Loeske & Moss & 91.09 & 3.350 & 396.35 \\
\hline Polytrichastrum alpinum (Hedw.) G.L. Smith & Moss & 31.41 & 0.565 & 49.17 \\
\hline Usnea aurantiaco-atra (Jacq.) Bory & Lichen & 25.13 & 0.544 & 38.81 \\
\hline Lecidea sciatrapha Hue & Lichen & 27.74 & 0.335 & 37.04 \\
\hline Ochrolechia frigida (Sw.) Lynge & Lichen & 27.22 & 0.277 & 34.77 \\
\hline Verrucaria sp. & Lichen & 22.51 & 0.246 & 28.05 \\
\hline Psoroma hypnorum (Vahl) Gray & Lichen & 14.65 & 0.214 & 17.80 \\
\hline Rhizocarpon polycarpum (Hepp) Th. Fr. & Lichen & 15.18 & 0.172 & 17.80 \\
\hline Sphaerophorus globosus (Huds.) Vain. & Lichen & 14.13 & 0.230 & 17.39 \\
\hline Andreaea regularis Muell. & Moss & 14.13 & 0.146 & 16.20 \\
\hline Rhizoplaca aspidophora (Vain.) Redón & Lichen & 12.56 & 0.125 & 14.14 \\
\hline Andreaea gainii Card. & Moss & 12.04 & 0.136 & 13.68 \\
\hline Cladonia rangiferina (L.) Weber ex F.H. Wigg. & Lichen & 10.47 & 0.120 & 11.73 \\
\hline Cladonia metacorallifera Asahina & Lichen & 9.94 & 0.099 & 10.93 \\
\hline Bryum of nivale Müll. Hal. & Moss & 8.89 & 0.146 & 9.82 \\
\hline Rhizocarpon geographicum (L.) DC. & Lichen & 8.37 & 0.083 & 9.07 \\
\hline Acarospora macrocyclos Vain. & Lichen & 7.85 & 0.078 & 8.47 \\
\hline Stereocaulon glabrum (Müll. Arg.) Vain. & Lichen & 7.32 & 0.104 & 8.09 \\
\hline Usnea antarctica Du Rietz & Lichen & 6.80 & 0.104 & 7.51 \\
\hline Prasiola crispa (Lightfoot) Kützing & Chlorophyta & 6.28 & 0.068 & 6.71 \\
\hline Cystocoleus niger (Huds.) Har. & Lichen & 6.28 & 0.062 & 6.67 \\
\hline Cladonia borealis S. Stenroos & Lichen & 5.75 & 0.083 & 6.24 \\
\hline Prasiola calophylla (Carmichael ex Greville) Kützing & Clorophyta & 5.75 & 0.078 & 6.21 \\
\hline Bryum argenteum Hedw. & Moss & 5.23 & 0.151 & 6.03 \\
\hline Hennediella heimii (Hedw.) Zand. & Moss & 5.23 & 0.052 & 5.50 \\
\hline Andreaea depressinervis Card. & Moss & 3.66 & 0.062 & 3.89 \\
\hline Himantormia lugubris (Hue) I.M. Lamb & Lichen & 3.14 & 0.036 & 3.25 \\
\hline Rhizoplaca melanophtalma (DC.) Leuckert \& Poelt & Lichen & 2.61 & 0.026 & 2.68 \\
\hline Polytrichum piliferum Hedw. & Moss & 2.09 & 0.031 & 2.16 \\
\hline Buellia latemarginata Darb. & Lichen & 2.09 & 0.026 & 2.14 \\
\hline Bryum pallescens Schleich. ex Schwägr. & Moss & 1.57 & 0.015 & 1.59 \\
\hline Huea austroshetlanica (Zahlbr.) C.W. Dodge & Lichen & 1.57 & 0.015 & 1.59 \\
\hline Microglaena antarctica I.M. Lamb & Lichen & 1.57 & 0.015 & 1.59 \\
\hline Pannaria hookeri (Borrer) Nyl. & Lichen & 1.57 & 0.015 & 1.59 \\
\hline Psoroma cinnamomeum Malme & Lichen & 1.57 & 0.015 & 1.59 \\
\hline Bartramia patens Brid. & Moss & 1.04 & 0.010 & 1.05 \\
\hline Buellia anisomera Vain. & Lichen & 1.04 & 0.010 & 1.05 \\
\hline Pohlia cruda (Hedw.) Lindb. & Moss & 1.04 & 0.010 & 1.05 \\
\hline Bryum pseudotriquetrum (Hedw.) Schwaegr. & Moss & 0.52 & 0.010 & 0.52 \\
\hline Buellia racovitzae C.W. Dodge & Lichen & 0.52 & 0.010 & 0.52 \\
\hline Bacidia tuberculata Darb. & Lichen & 0.52 & 0.005 & 0.52 \\
\hline Brachythecium austrosalebrosum (Müll. Hal.) Kindb. & Moss & 0.52 & 0.005 & 0.52 \\
\hline Bryum dichotomum Hedw. & Moss & 0.52 & 0.005 & 0.52 \\
\hline Buellia russa (Hue) Darb. & Lichen & 0.52 & 0.005 & 0.52 \\
\hline Caloplaca athallina Darb. & Lichen & 0.52 & 0.005 & 0.52 \\
\hline Ceratodon grossiretis Card. & Moss & 0.52 & 0.005 & 0.52 \\
\hline Haematomma eryhtromma (Nyl.) Zahlbr. & Lichen & 0.52 & 0.005 & 0.52 \\
\hline Lecanora skottsbergii Darb. & Lichen & 0.52 & 0.005 & 0.52 \\
\hline Pohlia nutans (Hedw.) Lindb. & Moss & 0.52 & 0.005 & 0.52 \\
\hline
\end{tabular}

lichens at different degrees of coverage, depending on the environmental conditions. These formations are usually found in the upper part of the hills, at sites of transitional communities like those between carpets of mosses and fruticose lichens.

The pure Andreaea spp. formations are generally colonized by Ochrolechia frigida. The carpets are colonized by crustose, foliose and fruticulose lichens. This is the case on the third plateau on the way to Xenia Hill's summit, at which a community of mosses formed by Polytrichastrum alpinum, Sanionia uncinata and Andreaea spp. occurs. These mosses are almost completely colonized by the lichens Cladonia spp., Ochrolechia frigida, Psoroma hypnorum, Sphaerophorus globosus and Stereocaulon glabrum.

Another muscicolous field is found near the edge of a cliff at the east point of the Xenia plateau, which is basically composed of Andreaea regularis Muell. and
Sanionia uncinata almost entirely covered by lichens such as Ochrolechia frigida, Cladonia spp. and Psoroma hypnorum.

\section{Crustose lichen community}

This community is composed of crustose lichens that develop on gravel, generally in low-altitude and plain areas close to the beach level where there is probably a strong maritime influence (wind and salinity) and plants remain covered by snow for long periods. These sites have strong nitrophilous influences due to the nearby penguin colonies, favouring ornithocoprophilous species. Taking into account the island's entire area, this community comprises a total of 39 plant species (Table 6) sampled in 67 quadrats $\left(\mathrm{E}=0.9239, \mathrm{H}^{\prime}=1.4700\right)$. These communities include sparse appearances by representative mosses and 
Table 5. Phytosociological data for the muscicolous lichen communities on Half Moon Island, including the frequency (F), coverage $(C)$ and IES for each species.

\begin{tabular}{|c|c|c|c|c|}
\hline Species & Group & $\mathrm{F}$ & C & IES \\
\hline Sanionia uncinata (Hedw.) Loeske & Moss & 82.60 & 2.021 & 249.62 \\
\hline Usnea aurantiaco-atra (Jacq.) Bory & Lichen & 65.21 & 1.956 & 192.81 \\
\hline Ochrolechia frigida (Sw.) Lynge & Lichen & 67.39 & 0.760 & 118.66 \\
\hline Sphaerophorus globosus (Huds.) Vain. & Lichen & 54.34 & 0.956 & 106.33 \\
\hline Polytrichastrum alpinum G.L. Smith & Moss & 54.34 & 0.760 & 95.69 \\
\hline Psoroma hypnorum (Vahl) Gray & Lichen & 50 & 0.782 & 89.13 \\
\hline Cladonia rangiferina (L.) Weber ex F.H. Wigg. & Lichen & 47.82 & 0.608 & 76.93 \\
\hline Cladonia metacorallifera Asahina & Lichen & 32.60 & 0.326 & 43.24 \\
\hline Verrucaria sp. & Lichen & 28.26 & 0.326 & 37.47 \\
\hline Stereocaulon glabrum (Müll. Arg.) Vain. & Lichen & 26.08 & 0.434 & 37.42 \\
\hline Andreaea regularis Muell. & Moss & 23.91 & 0.478 & 35.34 \\
\hline Rhizocarpon polycarpum (Hepp) Th. Fr. & Lichen & 23.91 & 0.239 & 29.63 \\
\hline Andreaea depressinervis Card. & Moss & 17.39 & 0.413 & 24.57 \\
\hline Lecidea sciatrapha Hue & Lichen & 19.56 & 0.239 & 24.24 \\
\hline Andreaea gainii Card. & Moss & 19.56 & 0.217 & 23.81 \\
\hline Rhizoplaca aspidophora (Vain.) Redón & Lichen & 13.04 & 0.173 & 15.31 \\
\hline Cladonia borealis S. Stenroos & Lichen & 10.86 & 0.195 & 12.99 \\
\hline Usnea antarctica Du Rietz & Lichen & 10.86 & 0.195 & 12.99 \\
\hline Physconia muscigena (Ach.) Poelt & Lichen & 10.86 & 0.152 & 12.52 \\
\hline Umbilicaria antarctica Frey \& I.M. Lamb & Lichen & 10.86 & 0.152 & 12.52 \\
\hline Microglaena antarctica I.M. Lamb & Lichen & 8.69 & 0.086 & 9.45 \\
\hline Prasiola crispa (Lightfoot) Kützing & Chlorophyta & 8.69 & 0.086 & 9.45 \\
\hline Acarospora macrocyclos Vain. & Lichen & 6.52 & 0.086 & 7.08 \\
\hline Psoroma cinnamomeum Malme & Lichen & 6.52 & 0.065 & 6.94 \\
\hline Rhizoplaca melanophtalma (DC.) Leuckert \& Poelt & Lichen & 6.52 & 0.065 & 6.94 \\
\hline Pohlia cruda (Hedw.) Lindb. & Moss & 4.34 & 0.086 & 4.72 \\
\hline Rhizocarpon geographicum (L.) DC. & Lichen & 4.34 & 0.043 & 4.53 \\
\hline Schistidium antarctici Card.) L.I. Savicz \& Smirnova & Moss & 2.17 & 0.065 & 2.31 \\
\hline Buellia latemarginata Darb. & Lichen & 2.17 & 0.043 & 2.26 \\
\hline Huea austroshetlandica (Zahlbr.) C.W. Dodge & Lichen & 2.17 & 0.043 & 2.26 \\
\hline Cystocoleus niger (Huds.) Har. & Lichen & 2.17 & 0.021 & 2.22 \\
\hline Hennediella heimii (Hedw.) Zand & Moss & 2.17 & 0.021 & 2.22 \\
\hline Himantormia lugubris (Hue) I.M. Lamb & Lichen & 2.17 & 0.021 & 2.22 \\
\hline Verrucaria tessellata (C.W. Dodge) Øvstedal & Lichen & 2.17 & 0.021 & 2.22 \\
\hline Pohlia nutans (Hedw.) Lindb. & Moss & 2.17 & 0.011 & 2.17 \\
\hline
\end{tabular}

fruticose lichens, which, in the future, could develop in other locations with favourable conditions..

The small peninsula that connects the hills at the north and middle-south of the island to the penguin rockery in the east are formed mainly of rounded rocks in deposits with plateau shapes. Each plateau has a distinct level of stability. In general, they have greater firmness in the centre of the island than at sites close to the sea. Apparently, erosion of the central plateaus is only affected anthropically. Amphibious vehicles used in 2008/09, for example, left tracks still visible in those sectors.

Depending on their altitudinal range and the depressions between each other, these areas are differently affected by wind and snow deposits. The higher sites are generally free from ice accumulation, while the depressions are generally covered by snow. However, the general geological structure does not allow for the formation or retention of soil, which allows only a saxicolous community to become established on the peninsula, except for a small part at the north and between each of the two straight-line formations found. The pebbles and rocks here are generally colonized by crustose lichens. Skuas use the area for nesting, generating some accumulation of finer particles, and such particulate pebbles and waste from the nests of birds allows the mosses to colonize these places, especially Sanionia uncinata and Polytrichastrum alpinum. An identical community is found on the east side of La Morenita Hill, at the plateau formed by the same kind of stones. Verrucaria spp., Buellia spp. and Lecidea spp. are the main crustose lichens in this community. Sanionia uncinata and Andreaea spp. are the main mosses represented, and are sometimes colonized by the lichen Ochrolechia frigida.

This community is present as three characteristic groups on the island. One of them is restricted to the penguin rockeries in the south, where the amount of guano is large. The second is found at the north and centre of the island, where the guano supply is smaller and comes from skuas and Cape petrels (Daption capense) nesting in the area. The third is very peculiar, since it is linked to the rounded small rocks exposed near the beach with the regression of the sea. Some animals (birds and pinnipeds) use these places as resting or molting points, depositing feathers and faeces on the rocks and generating an coprophilous community mainly composed of Acarospora macrocyclos. On the cliffs of Xenia Hill, there are also some examples of this community type, stimulated by the presence of guano deposited by Cape petrels at their nesting points. The main species in the areas are Haematomma erythromma and Xanthoria elegans (Polycauliona candelaria), covering the higher parts of the cliffs. 
Table 6. Phytosociological data for the crustose lichen communities on Half Moon Island, including the frequency (F), coverage (C) and IES for each species.

\begin{tabular}{|c|c|c|c|c|}
\hline Species & Group & $\mathrm{F}$ & $\mathrm{C}$ & IES \\
\hline Lecania brialmontii (Vain.) Zahlbr. & Lichen & 37.31 & 0.985 & 74.06 \\
\hline Buellia latemarginata Darb. & Lichen & 38.80 & 0.671 & 64.86 \\
\hline Sanionia uncinata (Hedw.) Loeske & Moss & 22.38 & 0.417 & 31.74 \\
\hline Acarospora macrocyclos Vain. & Lichen & 20.89 & 0.283 & 26.82 \\
\hline Turgidosculum complicatulum (Nyl.) Kohlm. \& E. Kohlm. & Lichen & 19.40 & 0.373 & 26.64 \\
\hline Haematomma eryhtromma (Nyl.) Zahlbr. & Lichen & 17.91 & 0.373 & 24.59 \\
\hline Rinodina petermannii (Hue) Darb. & Lichen & 16.41 & 0.477 & 24.25 \\
\hline Verrucaria sp. & Lichen & 17.91 & 0.238 & 22.18 \\
\hline Prasiola crispa (Lightfoot) Kützing & Chlorophyta & 17.91 & 0.194 & 21.38 \\
\hline Caloplaca regalis (Vain.) Zahlbr. & Lichen & 14.92 & 0.313 & 19.60 \\
\hline Xanthoria candelaria (L.) Th. Fr. & Lichen & 14.92 & 0.238 & 18.48 \\
\hline Candelaria murrayi Poelt & Lichen & 13.43 & 0.238 & 16.64 \\
\hline Lecidea sciatrapha Hue & Lichen & 13.43 & 0.223 & 16.44 \\
\hline Pannaria hookeri (Borrer) Nyl. & Lichen & 13.43 & 0.194 & 16.03 \\
\hline Bacidia tuberculata Darb. & Lichen & 11.94 & 0.238 & 14.79 \\
\hline Usnea aurantiacoatra (Jacq.) Bory & Lichen & 11.94 & 0.149 & 13.72 \\
\hline Rhizoplaca aspidophora (Vain.) Redón & Lichen & 11.94 & 0.119 & 13.36 \\
\hline Parmelia saxatilis (L.) Ach. & Lichen & 8.95 & 0.253 & 11.22 \\
\hline Xanthoria elegans (Link) Th. Fr. & Lichen & 7.46 & 0.149 & 8.57 \\
\hline Buellia anisomera Vain. & Lichen & 7.46 & 0.134 & 8.46 \\
\hline Ramalina terebrata Hook. f. \& Taylor & Lichen & 7.46 & 0.134 & 8.46 \\
\hline Andreaea regularis Muell. & Moss & 7.46 & 0.074 & 8.01 \\
\hline Hennediella antarctica (Angstr.) Ochyra \& Matteri & Moss & 7.46 & 0.074 & 8.01 \\
\hline Syntrichia magellanica (Mont.) R.H. Zander & Moss & 7.46 & 0.074 & 8.01 \\
\hline Mastodia tessellata (Hook. f. \& Harv.) Hook. f. \& Harv. & Lichen & 5.97 & 0.104 & 6.59 \\
\hline Rhizocarpon geographicum (L.) DC. & Lichen & 5.97 & 0.059 & 6.32 \\
\hline Rhizocarpon polycarpum (Hepp) Th. Fr. & Lichen & 5.97 & 0.059 & 6.32 \\
\hline Polytrichastrum alpinum G.L. Smith & Moss & 4.47 & 0.059 & 4.74 \\
\hline Psoroma cinnamomeum Malme & Lichen & 4.47 & 0.044 & 4.67 \\
\hline Usnea antarctica Du Rietz & Lichen & 4.47 & 0.044 & 4.67 \\
\hline Microglaena antarctica I.M. Lamb & Lichen & 2.98 & 0.044 & 3.11 \\
\hline Andreaea gainii Card. & Moss & 2.98 & 0.029 & 3.07 \\
\hline Caloplaca cinericola (Hue) Darb. & Lichen & 2.98 & 0.029 & 3.07 \\
\hline Ochrolechia frigida (Sw.) Lynge & Lichen & 2.98 & 0.029 & 3.07 \\
\hline Umbilicaria decussata (Vill.) Zahlbr. & Lichen & 2.98 & 0.029 & 3.07 \\
\hline Physconia muscigena (Ach.) Poelt & Lichen & 1.49 & 0.014 & 1.51 \\
\hline Rhizoplaca melanophtalma (DC.) Leuckert \& Poelt & Lichen & 1.49 & 0.014 & 1.51 \\
\hline Usnea acromelana Stirt. & Lichen & 1.49 & 0.014 & 1.51 \\
\hline Verrucaria tessellata (C.W. Dodge) Øvstedal & Lichen & 1.49 & 0.014 & 1.51 \\
\hline Bartramia patens Brid. & Moss & 0.14 & 0.007 & 0.15 \\
\hline
\end{tabular}

Table 7. Phytosociological data for the moss turf communities on Half Moon Island, including the frequency (F), coverage (C) and IES for each species.

\begin{tabular}{|c|c|c|c|c|}
\hline Species & Group & $\mathrm{F}$ & $\mathrm{C}$ & IES \\
\hline Polytrichastrum alpinum G.L. Smith & Moss & 72.22 & 2.055 & 220.67 \\
\hline Sanionia uncinata (Hedw.) Loeske & Moss & 50 & 1.166 & 108.33 \\
\hline Polytrichum piliferum Hedw. & Moss & 38.88 & 1.166 & 84.25 \\
\hline Ochrolechia frigida (Sw.) Lynge & Lichen & 50 & 0.666 & 83.33 \\
\hline Hennediella heimii (Hedw.) Zand. & Moss & 38.88 & 0.888 & 73.45 \\
\hline Rhizoplaca aspidophora (Vain.) Redón & Lichen & 38.88 & 0.388 & 54.01 \\
\hline Cladonia metacorallifera Asahina & Lichen & 33.33 & 0.333 & 44.44 \\
\hline Verrucaria sp. & Lichen & 27.77 & 0.277 & 35.49 \\
\hline Bryum argenteum Hedw. & Moss & 22.22 & 0.388 & 30.86 \\
\hline Cladonia rangiferina (L.) Weber ex F.H. Wigg. & Lichen & 22.22 & 0.333 & 29.62 \\
\hline Lecidea sciatrapha Hue & Lichen & 22.22 & 0.222 & 27.16 \\
\hline Pohlia cruda (Hedw.) Lindb. & Moss & 22.22 & 0.222 & 27.16 \\
\hline Ceratodon purpureus (Hedw.) Brid. & Moss & 22.22 & 0.166 & 25.92 \\
\hline Cystocoleus niger (Huds.) Har. & Lichen & 16.66 & 0.222 & 20.37 \\
\hline Andreaea regularis Muell. & Moss & 16.66 & 0.166 & 19.44 \\
\hline Psoroma cinnamomeum Malme & Lichen & 16.66 & 0.166 & 19.44 \\
\hline Usnea aurantiacoatra (Jacq.) Bory & Lichen & 11.11 & 0.111 & 12.34 \\
\hline Andreaea depressinervis Card. & Moss & 5.55 & 0.277 & 7.09 \\
\hline Acarospora macrocyclos Vain. & Lichen & 5.55 & 0.055 & 5.86 \\
\hline Andreaea depressinervis Card. & Moss & 5.55 & 0.055 & 5.86 \\
\hline Bartramia patens Brid. & Moss & 5.55 & 0.055 & 5.86 \\
\hline Buellia anisomera Vain. & Lichen & 5.55 & 0.055 & 5.86 \\
\hline Buellia latemarginata Darb. & Lichen & 5.55 & 0.055 & 5.86 \\
\hline Chorisodontium acyphyllum (Hook. f. \& Wills.) Broth. & Moss & 5.55 & 0.055 & 5.86 \\
\hline Prasiola crispa (Lightfoot) Kützing & Chlorophyta & 5.55 & 0.055 & 5.86 \\
\hline Psoroma hypnorum (Vahl) Gray & Lichen & 5.55 & 0.055 & 5.86 \\
\hline Rhizocarpon geographicum (L.) DC. & Lichen & 5.55 & 0.055 & 5.86 \\
\hline Rhizocarpon polycarpum (Hepp) Th. Fr. & Lichen & 5.55 & 0.055 & 5.86 \\
\hline Rhizoplaca melanophtalma (DC.) Leuckert \& Poelt & Lichen & 5.55 & 0.055 & 5.86 \\
\hline Sphaerophorus globosus (Huds.) Vain. & Lichen & 5.55 & 0.055 & 5.86 \\
\hline
\end{tabular}


Significant ornithocoprophilous communities are found in seven areas of the island. One is located at the extreme north of the island, on a shallow cliff near the seashore that is almost completely covered by Nacella concina shells in some places. The area is covered mainly by foliose/fruticose lichens such as Rinodina pettermanii and Haematoma erythromma, and also by crustose ones, for example Buellia spp. This place was the only one on the island where we found Usnea acromelana.

At two sites near Camara Base two giant rock fragments sometimes used by kelp gulls and skuas are covered by nitrophilous communities. Other hills used by gulls are situated inside the penguin colonies and, therefore, are influenced by them. The two isolated rocks are mainly covered by crustose lichens, such as Acarospora macrocyclus, Bacidia sp. and Rhizoplaca aspidophora.

\section{Moss turf community}

Eighteen quadrats were sampled and 30 plant species were identified in this formation $(E=0.9024$, $\left.\mathrm{H}^{\prime}=1.3330\right)$, which includes species of mosses, lichens and algae. This community is found at four sites of the island, three of which are located at higher altitudes on the tops of La Morenita, Gabriel and Xenia hills. The other formation is at the entrance of the penguin colony at Baliza Point, located in a transition area composed of pebbles, ornithocoprophilous plant communities and sparse carpets of S. uncinata. There is a constant presence of fur seals at this site. The moss species with high ecological significance in this community were Pohlia sp., Polytrichastrum alpinum and S. uncinata (Table 7). Crustose lichens have also been identified in association with the moss species, totalling six distinct species.

\section{Discussion}

Estimating of the extent and coverage of plant communities is important to assess their ecological relationships with different attributes of the physical environment, such as soil, rocks and the landscape, in greater detail (Simas et al. 2008). Our results indicated that Sanionia uncinata has the highest IES value on Half Moon Island (234.81), followed by Usnea aurantiacoatra (63.17) and Polytrichastrum alpinum (49.63). On Half Moon Island, the grass Deschampsia antarctica had an IES of only 0.28 because its frequency was very low $(0.28 \%)$, which was probably due to the small size of seabird colonies, as the association of this grass species with ornithogenic soils has been observed in other areas of maritime Antarctica (Emslie et al. 2014). In the vicinity of Arctowski Station (Poland) in Admiralty Bay, King George Island, Victoria et al. (2009) and Pinto et al. (2013) found that the maximum IES was observed for Deschampsia antarctica (245 and 358, respectively), followed by Sanionia uncinata (215 and 269, respectively) and Polytrichastrum alpinum (153 and 81 , respectively). In this study, we found that the area with grass is not generally used by bird colonies, being used mostly by a few skuas as a nesting point. In two areas with grass on Half Moon Island, Esponda et al. (2000) counted only five and two skua nesting pairs, respectively. The opposite occurred at Arctowski, as the areas colonized by $D$. antarctica there have large nutrient input rates due to the presence of penguin colonies. The occurrence of Antarctic hair-grass is important to landscape changes since the presence of the grass in plant communities generates changes in several factors in the Antarctic soil. The grasses increase the carbon input to the soil, which modifies exudate input and rhizosphere microbial diversity (Teixeira 2010; Teixeira et al. 2013), as well as soil genesis. The adaptive success of this plant in Antarctica is related to its efficient nitrogen acquisition from guano sources (Hill et al. 2011).

Analysing the diversity indices presented in Table 2 and Fig. 3, it can be observed that the crustose lichen community is the most diverse on Half Moon Island as indicated by the highest Shannon diversity index $\left(\mathrm{H}^{\prime}\right)$ and even greater evenness $(\mathrm{J})$; despite it not being the most species-rich it is a more homogeneous community in which no species stands out as being dominant over all others. The moss carpet community, in turn, has the highest species richness (51), although it does not have the greatest diversity and even has the lowest evenness. This is due to the fact that $S$. uncinata stands out as the dominant species in this community.

A previous study conducted at Hennequin Point on King George Island in the austral summer of 2004/05 (Victoria et al. 2013) showed some similar communities to those found herein on Half Moon Island, but with different indices. The moss carpet community of Hennequin Point was also the most species-rich one there, but the number of species was lower (28) and it was also the most homogeneous community in that study. Fruticose and crustose lichens were also found; however, these were classified as being within the same community, featuring only 28 species. The number of species of both fruticose and crustose lichens at Hennequin was relatively lower than that observed on Half Moon Island (Table 2), where fruticose and crustose lichens are not found in the same communities.

The fruticose lichen community on Half Moon Island is similar to that reported by Lindsay (1971), but with the Andreaea moss cushion presence only in isolated spots, forming associations similar to those described by that author. Accordingly, there is only one association (Andreaea-Usnea) in this community, and five associations. The associations found on Half Moon Island in this community are UsneaLecidea-Andreaea and Andreaea-Ochrolechia frigida. 
The other three associations with Himantormia lugubris described by Lindsay (1971) in the South Shetlands were not found in this study; although some small patches of this species were observed, very sparsely distributed, they were not abundant enough to be described as an association. The exposure to high salinity is probably hampering their growth, since the island is too small to protect them from maritime influences.

The formations of the moss carpet community, in which S. uncinata appeared most often, were found near drainage lines or sites under the influence of water originating from melting glaciers or lakes, as observed in Admiralty Bay, King George Island (Victoria et al. 2009; Victoria et al. 2013). Spots in which several species have developed in association with S. uncinata were also found. Therefore, the same conditions that favour S. uncinata appear to promote adequate conditions for other species of both mosses and muscicolous lichens in these places, even in the absence of glaciers in the area studied in this work.

The crustose lichen community has the greatest area of vegetation cover on the island and, in addition, is the most diverse. Generally, this community is located in areas where the island birds and penguin colonies are concentrated. Important conditions for some species are developed there. The direct relationship between the vegetation and the presence of nests is linked to the fact that birds provide the majority of nutrients for the initial development of plants, since the emergence of plant communities is subsequent to the establishment of nests (Allen et al. 1967; Leishman \& Wilde 2001; Smykla et al. 2007).

In the study by Lindsay (1971), the lichen community was composed mainly of crustose lichens, although fruticose lichens could attain appreciable cover and occur on rock surfaces, particularly those subjected to wind and salt spray. At the location of this study, a high coverage by the crustose lichen Verrucaria spp. can be observed, which is specifically associated with fresh or salt water (Olech 2004) and exposure to wind.

At Hennequin Point, King George Island, Victoria et al. (2013) found that there was a community sociation with fruticulose lichens, where they described Usnea aurantiaco-atra, Mastodea tesselata (Hook. f. \& Harv.) Hook. f. \& Harv., and Lecania brialmontii (Vain.) Zahlbr. as the most common species. The last two, which are usually associated with colonies of birds and occur along with other ornitocoprophilous species, were not found at comparable locations on Half Moon Island.

The formation located on the top of La Morenita Hill resembles the sociation of Polytrichastrum alpinum-Polytrichum piliferum Hedw. described by Lindsay (1971), in which these two mosses did not form extensive turfs but occurred in small colonies that formed low piles and irregular loafs. The flat top of the hill allows the development of mosses such as $S$. uncinata and representatives of the family Polytrichaceaea. There are other mosses on the hill formation, such as Bryum argenteum and Ceratodon sp., which develop among the same conditions as those preferred by the species referred to above. Fruticose and crustose lichen assemblages are also developed on the rocks nearby.

Verrucaria species (except $V$. tessalata) were found in all communities in most of the sites studied on Half Moon Island, except at the top of La Morenita and Xenia hills and on the slope and beach on the north side of Xenia Hill, i.e., areas that are probably protected from the east-west winds acting on the island. The only plant community in which Verrucaria spp. were not present is that predominated by fruticose lichens, which occurs mainly on the north slope of Xenia Hill. According to Olech (2004), Verrucaria species spp. were found on rocks in the spray zone above high-tide level. This indicates that the area is constantly sprayed by marine salt, especially because it is a very small island, which explains the frequent presence of these halophilous species.

Colobanthus quitensis (Caryophyllaceae) was not found on Half Moon Island. This species and the grass Deschampsia antarctica are the only native angiosperms found in the South Shetlands Islands and the maritime Antarctic, reaching as far south as $68^{\circ} 42^{\prime} \mathrm{S}$ along the Antarctic Peninsula (Moore 1970; Edwards \& Lewis-Smith 1988; Putzke \& Pereira 2001; Olech 2004; Parnikoza et al. 2007). Colobanthus quitensis is abundant in lower coastal regions, where it forms dense communities and occupies large areas associated with $D$. antarctica in all the South Shetland Islands. Vera (2011) reported the occurrence of $C$. quitensis at Livingston Island (located south-east of Half Moon Island) and proposed that its distribution there is related to the island's geomorphology, suggesting that it only grows in more interior areas and at higher altitudes, where the types of other vegetation that can persist become more restricted. Its dispersion is favoured by skuas for nesting, but can also occur with strong winds. These environmental factors are also found on Half Moon Island: it is a small island, with different altitudinal ranges, strong winds, and the presence of nesting skuas. However, no C. quitensis was found in our survey, suggesting that the soil condition, the size of bird colonies or the maritime influence on Half Moon Island might have affected its development or establishment there. 


\section{Conclusions}

Comparing the plant communities of the ice-free areas on Half Moon Island with those described at Stinker Point, Elephant Island, by Pereira \& Putzke (1994), Rip Point, Nelson Island, by Putzke et al. (1998), the region of Arctowski, Admiralty Bay, King George Island by Victoria et al. (2009), Hennequin Point, King George Island, by Victoria et al. (2013), Demay Point, King George Island, by Pereira et al. (2010) and Keller Peninsula, King George Island, by Pereira et al. (2007), it was possible to make the following conclusions.

Moss turf communities were found only in a small area and were difficult to clarify on account of the absence of key species in these communities. For example, Chorisodontium aciphyllum (Hook. f. \& Wills.) Broth and Polytrichum juniperinum Hedw. are considered the moss tuft species most observed in this type of formation, but they were not found on Half Moon Island. We found only Polytrichastrum alpinum Hedw., but its low coverage and frequency made it extremely difficult to define this community based on this species in this study. However, the physiognomy observed in these small sites allow us to suggest the occurrence of this formation on the island.

Among the flowering plants, only Deschampsia antarctica was found on Half Moon Island, while Colobanthus quitensis (Caryophyllaceae) was absent, in spite of its occurrence in the surrounding islands. Because of the scarcity of soil on the island, the grass $D$. antarctica presented low coverage and low ecological importance indices.

Ornithocoprophobous species are rare on Half Moon Island on account of guano inputs, as is the case on almost all islands in this region. Polytrichum juniperinum and Placopsis antarctica D.J. Galloway, Lewis-Sm. \& Quilhot. were absent. The ornithocoprophilous lichen community is restricted to the eastern extremity of the island, the penguin rockeries are, and to the north-east cliffs, where Cape petrels are found. The crustose lichen community is well represented on Half Moon Island, since there are many areas where these lichens completely cover rock fragments.

\section{Disclosure statement}

No potential conflict of interest was reported by the authors.

\section{Funding}

This work was supported by the Brazilian Antarctic Program through the National Council for Research and Development (CNPq; process no. 574018/2008), the Research Foundation of the State of Rio de Janeiro
(FAPERJ; process E-26/170.023/2008), the Ministry of Science, Technology and Innovation (MCTI), the Interministerial Commission for Sea Resources (CIRM), and the Foundation for Research Support of Rio Grande do Sul State (FAPERGS), from which the authors appreciate the financial and logistic support that was needed to carry out this work. We also would like to acknowledge the Argentine Camara Base crew, under the command of Capitán de Corbeta de Infantería de Marina Hector Daniel Baez Mannino, and thank the Argentine Antarctic Program for the facilities arranged for us during our stay on Half Moon Island.

\section{ORCID}

Daniela Schmitz (1) http://orcid.org/0000-0002-3162-2430 Margéli Pereira de Albuquerque (D) http://orcid.org/00000002-8945-5030

Adriano Luis Schünemann (1) http://orcid.org/0000-00017227-7074

Filipe de Carvalho Victoria (D) http://orcid.org/0000-00028580-1813

Antônio Batista Pereira (D) http://orcid.org/0000-00030368-4594

\section{References}

Allen S.E., Grimshaw H.M. \& Holdgate M.W. 1967. Factors affecting the availability of plant nutrients on an Antarctic island. The Journal of Ecology 55, 381-396.

Bender N.A., Crosbie K. \& Lynch H.J. 2016. Patterns of tourism in the Antarctic Peninsula region: a 20-year analysis. Antarctic Science 28, 194-203.

Braun-Blanquet J. 1964. Pflanzensoziologie. (Phytosociology.) 3rd ed. Vienna: Springer.

Chwedorzewska K.J., Giełwanowska I., Szczuka E. \& Bochenek A. 2008. High anatomical and low genetic diversity in Deschampsia antarctica Desv. from King George Island, the Antarctic. Polish Polar Research 29, 377-386.

Edwards J.A. \& Lewis-Smith R.I. 1988. Photosynthesis and respiration of Colobanthus quitensis and Deschampsia antarctica from the maritime Antarctic. British Antarctic Survey Bulletin 8, 43-63.

Emslie S.D., Polito M.J., Brasso R., Patterson W.P. \& Sun L. 2014. Ornithogenic soils and the paleoecology of pygoscelid penguins in Antarctica. Quartenary International 352, 4-15.

Esponda C.M.G., Coria N.R. \& Montalti D. 2000. Breeding birds at Halfmoon Island, South Shetland Islands, Antarctica, 1995/96. Marine Ornithology 28, 59-62.

Favero M. \& Silva M.P. 1991. The status of the breeding birds at Halfmoon Island (Isla Media Luna) South Shetland Islands, Antarctica. Contribuciones del Instituto Antártico Argentino 407, 1-8.

Hill P.W., Farrar J., Roberts P., Farrell M., Grant H., Newsham K.K., Hopkins D.W., Bardgett R.D. \& Jones D.L. 2011. Vascular plant success in a warming Antarctic may be due to efficient nitrogen acquisition. Nature Climate Change 1, 50-53.

Lara F. \& Mazimpaka V. 1998. Sucession of epiphytic bryophytes in Quercus pyrenaica forest from Spanish Central Range (Iberian Peninsula). Nova Hedwigia 67, 125-138.

Leishman M.R. \& Wilde C. 2001. Vegetation abundance and diversity in relation to soil nutrients and soil water content in Vestfold Hills, East Antarctica. Antarctic Science 13, 126-134. 
Lindsay D.C. 1971. Vegetation of the South Shetland Islands. British Antarctic Survey Bulletin 25, 59-83.

Ludwig J.A. \& Reynolds J.F. 1988. Statistical ecology. New York: John Wiley \& Sons.

Marques J., Hespanhol E., Vieira C. \& Séneca A. 2005. Comparative study of the bryophyte epiphytic vegetation in Quercus pirenaica and Quercus robur Woodlands from northern Portugal. Boletín de la Sociedad Española de Briología 26-27, 75-84.

Moore D.M. 1970. Studies in Colobanthus quitensis (Kunth) Bartl. and Deschampsia Antarctica Desv. II. Taxonomy, distribution and relationships. British Antarctic Survey Bulletin 23, 63-80.

Ochyra R. 1998. The moss flora of King George Island, Antarctica. Kracow: Institute of Botany, Polish Academy of Science.

Ochyra R., Lewis-Smith R.I. \& Bednarek-Ochyra H. 2008. The illustrated moss flora of Antarctica. New York: Cambridge University Press.

Olech M. 2004. Lichens of King George Island Antarctica. Krakow: Institute of Botany, Jagiellonian University.

Olrog C.C. 1958. Observaciones sobre La avifauna antártica y de alta mar desde El Río de la Plata hasta los $60^{\circ}$ de latitude sur. (Observations on Antarctic and high seas avifauna from El Río de la Plata to $60^{\circ}$ south latitude.) Acta Zoologica Lilloana 15, 19-33.

Øvstedal D.O. \& Lewis-Smith R.I. 2001. Lichens of Antarctica and South Georgia: a guide to their identification and ecology. Cambridge: Cambridge University Press.

Øvstedal D.O. \& Lewis-Smith R.I. 2004. Additions and corrections to the lichens of Antarctica and South Georgia. Cryptogamie, Mycologie 25, 323-331.

Øvstedal D.O. \& Schaefer C.E.G.R. 2013. A new lichen species from the Heritage Range, Ellsworth Mountains, Antarctica. Hoehnea 40, 361-364.

Parnikoza I.Y., Maidanuk D.N. \& Kozeretska I.A. 2007. Are Deschampsia antarctica Desv. and Colobanthus quitensis (Kunth) Bartl. migratory relicts? Cytology and Genetics 41, 226-229.

Peet R.K. 1974. The measurement of species diversity. Annual Review of Ecology and Systematics 5, 285-307.

Pereira A.B. \& Putzke J. 1994. Floristic composition of Stinker Point, Elephant Island, Antarctica. Korian Journal of Polar Research 5, 37-47.

Pereira A.B., Francelino M.R., Stefenon V.M., Schünemann A.L. \& Roesch L.F. 2010. Plant communites from icefree areas of Demay Point, King George Island, Antarctica. In Y.Y. Valentin et al. (eds.): Annual activity report 2010. Pp. 58-62. Rio de Janeiro: National Institute of Science and Technology.

Pereira A.B., Spielmann A.A., Martins M.F.N. \& Francelino M.R. 2007. Plant communities from ice-free areas of Keller Península, King George Island, Antarctica. Oecologia Brasiliensis 11, 14-22.

Pinto G.N., Albuquerque M.P., Victoria F.C. \& Pereira A.P. 2013. Phytosociological study in ice-free areas of
Arctowski region, Admiralty Bay, King George Island, Antarctica. In Y.Y. Valentin et al. (eds.): Annual activity report 2013. Pp. 45-47. Rio de Janeiro: National Institute of Science and Technology.

Pitkanen S. 1998. The use of diversity indices to assess the diversity of vegetation in managed boreal forest. Forest Ecology and Management 112, 121-137.

Putzke J. \& Pereira A.B. 2001. The Antarctic mosses with special reference to the South Shetlands Islands. Canoas, Brazil: Editora da Ulbra.

Putzke J., Pereira A.B. \& Putzke M.T.L. 1998. Moss communities of Rip Point in Northern Island, South Shetland Islands, Antarctica. Pesquisa Antártica Brasileira 3, 104-115.

Redon J. 1985. Liquens Antárticos. (Antarctic lichens.) Santiago del Chile: Instituto Antártico Chileno.

Simas F.N.B., Schaefer C.E.G.R., Albuquerque-Filho M.R., Francelino M.R., Filho E.I.F. \& Da Costa L.F. 2008. Genesis, properties and classification of cryosols from Admiralty Bay, maritime Antarctica. Geoderma 144, 116122.

Smykla J., Wolek J. \& Barcikowski A. 2007. Zonation of vegetation related to penguin rookeries on King George Island, maritime Antarctic. Arctic, Antarctic and Alpine Research 39, 143-151.

Teixeira C.R.S.L. 2010. Bacterial diversity in rhizosphere soil from Antarctic vascular plants of Admiralty Bay, maritime Antarctica. The ISME Journal 4, 989-1001.

Teixeira L.C.R.S., Yeargeau E., Balieiro F.C., Piccolo M.C., Peixoto R.S., Greer C.W. \& Rosado A.S. 2013. Plant and bird presence strongly influences the microbial communities in soils of Admiralty Bay, maritime Antarctica. PloS One 8(6), e66109, doi: 10.1371/journal.pone.0066109.

Vera M.L. 2011. Colonization and demographic structure of Deschampsia antarctica and Colobanthus quitensis along an altitudinal gradient on Livingston Island, South Shetland Islands, Antarctica. Polar Research 30, article no. 7146, doi: 10.3402/polar. v30i0.7146.

Victoria F.C., Albuquerque M.P., Pereira A.B., Simas F.N.B., Spielmann A.A. \& Schaefer C.E.G.R. 2013. Characterization and mapping of plant communities at Hennequin Point, King George Island, Antarctica. Polar Research 32, article no. 19261, doi: 10.3402/polar.v32i0.19261.

Victoria F.C. \& Pereira A.B. 2007. Índice de valor ecológico (IES) como ferramenta para estudos fitossociológicos e conservação das espécies de musgos na Baía do Almirantado, Ilha Rei George, Antártica Marítima. (Index of ecological significance [IES] as a tool for phytosociological studies and conservation of moss species in Admiralty Bay, King George Island, maritime Antarctica.) Oecologia Brasiliensis 11, 50-55.

Victoria F.C., Pereira A.B. \& Costa D.P. 2009. Composition and distribution of moss formations in the ice-free areas adjoining the Arctowski region, Admiralty Bay, King George Island, Antarctica. Iheringia, Série Botanica 64, 81-91. 